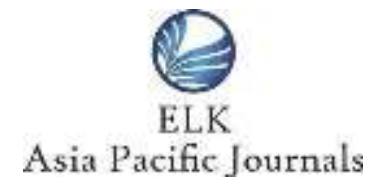

www.elkjournals.com

\title{
SOCIAL MARKETING: IMPACT OF ANTI-SMOKING ADVERTISEMENT AMONG MALE ADULTS IN COIMBATORE CITY
}

\author{
Dr.B.DIVYA PRIYA, \\ Associate Professor of Commerce, \\ Kongunadu Arts and Science College, \\ Coimbatore - 641029. \\ E-mail id: diya.kasc@gmail.com. \\ Mobile: + 919677709027
}

\begin{abstract}
Tobacco is a risk factor for six of the eight leading causes of deaths in the world. Every eight seconds someone, somewhere in the world, dies as a result of tobacco use. India has made progress on tobacco control in recent years. Prohibition to sell cigarettes to people who are below 18 years of age, levying fine on those persons who smoke at public places, anti-smoke campaign messages, etc., were few measures to prevent tobacco-related deaths. Increasing level of awareness towards tobacco consumption and risk associated in practicing such behaviours will be the way-out to prevent smoke-related deaths and disease. Anti-smoking advertisements are those advertisements that inform the smokers and the general public about the 'harmful-riskassociated with smoking', persuade and enable the smokers to alter and quit smoking and thus, bring out desired habitual change. The study was aimed to assess the impact of "anti-smoking advertisements" among male adults in Coimbatore city. It was found that vast majority of smokers' were aware about the harmful effects of smoking. Anti-smoking advertisement was clear enough to inform the public that 'smoking is not good for health'. The advertisement has made the smokers feel concerned about the 'evil-effect' of smoking on their own health as well as on the health of the person around them. Most of the respondents opined that graphic related warning was effective message format for anti-smoking campaign. But it was found only 57.3 per cent of the respondents support the regulation of smoking in public places. Strict law and action should be exercised to control over smoking in public place.
\end{abstract}

Keywords: Anti-smoking Advertisement, Attitude, Awareness, Habitual change, Impact, Regulation, Smoking.

\section{INTRODUCTION}

WHO described tobacco has 'the single greatest cause of preventable disease in the world'. Approximately 6 million deaths were the result of direct tobacco consumption while 890000 are non-smokers who breathe second-hand smoke ${ }^{1}$. India is the second largest consumer of tobacco in 


\section{ELK ASIA PACIFIC JOURNAL OF MARKETING \& RETAIL MANAGEMENT}

ISSN 2349-2317 (Online); DOI: 10.16962/EAPJMRM/issn. 2349-2317/2018; Volume 9 Issue 4 (2018)

the world ${ }^{2}$. National Institute of Cancer Prevention and Research (NICPR) reported, in India more than $35 \%$ of adults $(274.5$ million) use tobacco, of this 163.7 million use only smokeless tobacco; 68.9 million are only smokers while 42.3 million users of both smoking and smokeless tobacco ${ }^{3}$. According to a report by the Indian Council of Medical Research (ICMC), tobacco accounts for about 30 per cent of all cancers in men and women in India 4

Booth (2003) described smoking across a person's life span as "an entrenched behaviour which is difficult to alter and thus, required more communication intervention" $"$. World Health Organization (WHO) recommends five policies for controlling tobacco use: smoke-free environments; support programmes for tobacco users who wish to stop; health warnings on tobacco packs; bans on the advertising, promotion and sponsorship of tobacco; and higher taxation of tobacco ${ }^{6}$. Despite the ban on advertising and sale of tobacco products to minors and smoking in public places, India was the weakest regime for warning the public against tobacco use ${ }^{7}$. There is a need to apply different strategies to warn smokers against negative consequences of smoking.
In India, several strategies like anti-smoking advertisement, Rehab centres, Anti-smoking convention, a dedicated toll-free number (Quit Line - 1800227787) to restrain addicted behaviour, taxes, and medicines, Nicotine Gum / Patch have been used to warn smokers about the risks associated with smoking to reduce and rescue them from tobacco-consumption at base.

\section{ANTI-SMOKING}

\section{CAMPAIGN/ANTI-SMOKING} ADVERTISEMENT:

"Anti-smoking Campaign" is an activity allied to inform and warn smokers' as well as the general public about harmful effects of smoking, and thereby help alter or reject smoking. These advertisements should influence the targeted audience by social normative beliefs and enhance the perceived ability to resist pressures for tobacco-smokeconsumption. Anti-smoking advertisement applies social marketing principles and techniques (usually an advertisement, or a message) to persuade target audience (smokers) behaviours that will benefit (to reduce, resist and reject smoking) an individual and the society, as a whole. Social marketing consists of two subsets: social advocacy and social advertising (Smith, 1998) ${ }^{8}$. Social advocacy is to 


\section{ELK ASIA PACIFIC JOURNAL OF MARKETING \& RETAIL MANAGEMENT}

ISSN 2349-2317 (Online); DOI: 10.16962/EAPJMRM/issn. 2349-2317/2018; Volume 9 Issue 4 (2018)

address structural changes (to insist smokers' not to light a cigarette in public places and imposing fine if they violate the law) while social advertising is to create awareness regarding detrimental cause of tobacco smoke (usually a message, healthrelated warnings, etc).

Social advertisement effectiveness is measured based on the following criteria viz., Publicity, Periodicity, Actuality, Reachability and Recollection. These criteria help to attain desired changed behaviour in people ${ }^{9}$. Publicity - Message content and format were reasonably accessible to the general public, Periodicity - Frequency of viewing such ads, Actuality - Publishing facts and figures (smokerelated consequences and deaths), Reachability - how fast it reaches the targeted audience and Recollection memory, mental process of retrieving information (how persuade). These criteria should be checked on anti-smoking campaign to know how effective these campaigns' are to reach the smokers', persuade and aid to alter behaviour in them.

\section{STATEMENT OF THE PROBLEM}

Tobacco is a risk factor for six of the eight leading causes of deaths in the world. Every eight seconds someone, somewhere in the world, die as a result of tobacco use. In India, around 9,00,000 lakh of people are killed by tobacco use. It is a serious public health issue and is threatening the life of people resulting in premature death. It harms the health, wealth and the spirit of India as a whole. Effective tobacco control should be on top priority. Prohibition to sell cigarettes to people who are below 18 years of age, levying fine on those persons who smoke at public places, etc., were some control aids of Indian government to reduce tobacco consumption and death. Apart from these control measures, the government of India, in order to create awareness on effects of smoking consumption has launched antismoking campaign. It is an advertisement or an announcement on ill-effects of smoking. In simple terms, anti-smoking advertisements are those advertisements that inform the smokers and the general public about the 'harmful-risk-associated with smoking', make aware, persuade and enable the smokers to alter and quit smoking and thus, bring out desired habitual change. In this context, it becomes necessary to check the level of awareness towards ill-effects of smoking, attitude of smokers towards smoking in general places, effective media to reach the targeted audience, effectiveness 


\section{ELK ASIA PACIFIC JOURNAL OF MARKETING \& RETAIL MANAGEMENT}

ISSN 2349-2317 (Online); DOI: 10.16962/EAPJMRM/issn. 2349-2317/2018; Volume 9 Issue 4 (2018)

of anti-smoking advertisement and impact of such campaign. Thus, the researcher tried to assess the effectiveness and impact of antismoking advertisement among smokers in Coimbatore city.

\section{OBJECTIVES OF THE STUDY}

The study aims at the following objectives:

$>$ To assess the awareness level related to illeffects and attitude of smokers' towards smoking

$>$ To examine the effective media and message format to promote "Anti-Smoking Campaign"

$>$ To find out the effectiveness of "Antismoking Campaign"

To analyse the impact created by "AntiSmoking Campaign"

\section{METHODOLOGY}

The data used in the study comprises of both primary and secondary data. Respondents were smokers and were identified through snowball sampling method, since population was hard-to-reach and sample consisted of 150 respondents. They were interviewed following a semi-structured schedule among folks sharing cigarettes and water-pipe in cafes, in their homes and other important places. The schedule consisted of awareness related to ill-effects of smoking, attitude of smoking in public places, effective media, message format of anti smoking advertisement, its effectiveness and impact. Secondary source of data were collected from e-journals, newspapers, books and magazines. The study was conducted in Coimbatore city. Descriptive statistical tools: percentage analysis, mean score analysis and ranking scale order were used in the study.

\section{ANALYSIS}

AND

\section{INTERPRETATIONS:}

\subsection{SMOKE-RELATED \\ AWARENESS AND ATTITUDE}

\subsubsection{Awareness related to ill-effects of Smoking:}

Awareness is an ability to integrate sensations from the environment with one's immediate goals and feelings to guide behaviour (Wikipedia) ${ }^{10}$. It is the quality or state of being aware of. Table 1 depicted the smoker's awareness towards consequences of smoking. It was found that 96 per cent of the respondents were aware that 'Cigarette smoking can cause serious harm to one's health' while 4 per cent of the, were not. 92 per cent of the respondents were aware 'Exposure to smoke from another person's cigarette causes heart attack' where 8 per 


\section{ELK ASIA PACIFIC JOURNAL OF MARKETING \& RETAIL MANAGEMENT}

ISSN 2349-2317 (Online); DOI: 10.16962/EAPJMRM/issn. 2349-2317/2018; Volume 9 Issue 4 (2018)

cent of them were unaware. It can be concluded that vast majority of the respondents were aware about the adverse effect of smoking.

\subsubsection{Attitude of smoker's towards regulation of smoking in public places:}

Section 3 of the Cigarette and Other Tobacco Product Act (The COTPA), 2003, prohibits smoking in public places. "Public place" means any place to which the public have access whether as of right (or) not, and includes all places visited by general public namely, auditorium, hospital buildings, railways waiting room, amusement centers, public offices, bus stops, educational institutions, libraries, coffee houses, canteens, banks, clubs and also open space surroundings, hotels/restaurants, etc. Also, in 2008, the Ministry of Health and Family Welfare notified the Prohibition of Smoking in Public Places Rules, 2008, by which smoking in public places are prohibited from October 2, 2008. Any person caught smoking in public must pay a fine of ₹ $200^{11}$. Attitude of Smokers' towards regulation of smoking in public place were examined. It was found that 57.3 per cent of the respondents support the regulation of smoking in public places while 42.7 per cent of them will never support the regulation of smoking in public places (Table 2).

\subsection{IMPACT OF ANTI-SMOKING ADVERTISEMENT}

\subsubsection{Effective media to promote Anti-} smoking Advertisement:

Media plays a vital role in educating and creating awareness on various social issues among the public. Media act as an agent of change that could steer in development by disseminating social messages constantly, to enhance the quality of living of the people ${ }^{11}$. In India, anti-smoking advertisements were usually sponsored and promoted by different entities like media, government/ministry, NGOs', companies / hospital corporate, schools / colleges, International Organization and Social Activist. But, it has to join hands with media to reach the masses. Smokers were asked to rank the effective media to sell and promote 'Antismoking advertisement' according to their priority and preference.

The study revealed that 'Ad in Cinema theatres/in film advertisement (Antismoking Ad before movie)' has secured the first rank (4.32). 'Television and Radio' obtained second rank (4.29) and 'Transit Advertising and wraps' secured third rank 


\section{ELK ASIA PACIFIC JOURNAL OF MARKETING \& RETAIL MANAGEMENT}

ISSN 2349-2317 (Online); DOI: 10.16962/EAPJMRM/issn. 2349-2317/2018; Volume 9 Issue 4 (2018)

(4.20). Subsequent ranks were given to posters, banners, hoardings and billboards (3.9), Schools and Colleges (3.88), Social media (3.86). Least rank was obtained by Newspapers, pamphlets and magazines (3.84). Thus it was clear that 'Ad in Cinema theatres/In film advertisement (Antismoking Ad before movie)' and 'television and radio' was the effective communication strategy to reach masses, to build and support tobacco control policies and prompt people to quit smoking (Table 3).

\subsubsection{Message format of Anti-smoke Advertisement viewed:}

In social advertisement, an appeal refers to the keyword or tagline or a message format that is used to define a social cause. It may also include cartoons, fear images and information about facts and statistical figures relating to social cause. An advertisement appeal were the 'heart' of the social message; 'pull-string' the eyes and ears of the viewers' and thus, create a sensible touch to promote and fight for the social cause. Anti-smoking advertisement usually appealed in the form of Illness, social acceptance ads, graphic health warnings, health-related warnings on cigarette pack and fear-appeal based. Table
4 depicted the effective message format to promote 'anti-smoking advertisement'.

It was found that 40 per cent of smokers' opined that 'graphic health warnings' were effective message format, 31.3 per cent opined that 'health-related warnings on cigarette pack itself' were effective, 20.7 per cent opined with 'Illness/ Social acceptance Ads' while 8 per cent opined that 'fear appeal and emotional ads' were effective format to promote antismoking advertisement (Table 4).

\subsubsection{Frequency of viewing Anti-smoking Advertisement:}

Anti-smoking advertisement are repeatedly shown, so that the message gets lodged in the sub conscious mind of the smokers and affect the behaviour. Smokers' were asked to assess in order to measure the frequency of viewing anti-smoking advertisement.

(Table 5) projected the frequency of viewing and listening to anti-smoking advertisement. It was seen 24.7 per cent of the respondents viewed anti-smoking advertisement regularly, 27.3 per cent of them viewed anti-smoking advertisement occasionally, and 28 per cent viewed antismoking advertisement only when necessity arose, 12 per cent of them viewed antismoking advertisement during leisure time 


\section{ELK ASIA PACIFIC JOURNAL OF MARKETING \& RETAIL MANAGEMENT}

ISSN 2349-2317 (Online); DOI: 10.16962/EAPJMRM/issn. 2349-2317/2018; Volume 9 Issue 4 (2018)

and the rest 8 per cent viewed anti-smoking advertisement at some unavoidable situation. Thus, it can be concluded that smokers' refer and view anti-smoking advertisement only when necessity arose. Most smokers' (78 out of 150 in numbers) viewed anti-smoking campaign regularly and occasionally.

\subsubsection{Effectiveness of 'Anti-} smoking' Advertisement:

Anti-smoking mass media campaigns aims to create awareness and knowledge about the ill-effects of smoking to the smokers and non-smokers in order to curb smoking and thereby, reduce smoke-related deaths. These campaigns were telecasted at substantial cost or cost-free and usually sponsored by Government of India/Ministry of Health and Family Welfare, NGO's, Companies, Hospital Corporate, Social Activist, International Organization and Educational Institutions. Effectiveness and Impact of 'Anti-smoking' Ad were measured based on the message acceptance (how viewers accepted the anti-smoke message), perceived effectiveness (how effective it was in delivering that message), and behavioral intention (whether the anti-smoke advertisement made the viewer think about changing their behavior).
Effectiveness of anti-smoking advertisement was assessed through mean rating. 5-point Likert scale ranging from "1" ("Strongly Disagree") to "5" ("Strongly Agree") was constructed. A higher mean rating indicates agreement with the statement than a lower mean rating. Ten statements were framed based on 'effectiveness' criteria on antismoking advertisement.

From table 6, it was found that greater agreement (Mean rating $>70$ per cent) were secured by the following statement: 'Antismoking advertisement was clear enough to inform the public that smoking is not good for health (mean rating 4.15)', 'Antismoking advertisement talked down to me (Mean rating 3.72)', 'Anti-smoking advertisement had a social message that is important to me (Mean rating 3.52)', and 'Anti-smoking advertisement made me stop and think about quitting smoking (Mean rating 3.43)'. Lower disagreement was obtained by the statement 'Anti-smoking advertisement gave me information related to Rehab centers and quit line toll-free number (Mean Rating 2.99)'. Moreover, standard deviation (SD) was lower in this statement when compared to other statement.

Thus, it was concluded that anti-smoking advertisement was clear enough to inform 
ISSN 2349-2317 (Online); DOI: 10.16962/EAPJMRM/issn. 2349-2317/2018; Volume 9 Issue 4 (2018)

the public that 'smoking is not good for health'. It had a 'social message' that talked down to smokers and made him to stop and think to quit smoking. But, the ad should also include information related to Rehab centers and quit line number for consultation and speedy recovery from smoking.

\subsubsection{Recollection of Message type of Anti-smoking}

Advertisement:

Recollection is the ability or an act of remembering something that one has learned and experienced. Respondents were asked to measure the best message format of antismoking advertisement. Table 7 revealed that:

a) Illness ads/Social Acceptance Ads: 40 per cent of the smokers' have high recollection, 39.3 per cent have low recollection and 20.7 per cent of them have no recollection towards 'Illness/Social Acceptance' message format of anti-smoking advertisement.

b) Graphic health warnings: 32 per centof the smokers' have high recollection, 27.3 have low recollection and 40.7 per cent of them have no recollection towards 'Graphic health warnings'. c) Health-related warnings on Cigarette pack: 36.7 per cent of the smokers' have high recollection, 24 per cent have low recollection and 39.3 per cent of them have no recollection towards 'Health-related warnings on cigarette pack'.

d) Fear appeal based and Emotional Ads: 28.7 per cent of the smokers' have high recollection, 43.3 per cent have low recollection and 28 per cent of them have no recollection towards 'fear appeal based and emotional ads'.

\subsubsection{Impact of Anti-Smoking}

\section{Advertisement:}

Anti-smoking advertisement aimed to bring out the desired habitual change in an individual i.e. to enable the smokers' to quit smoking. Respondents were asked to measure the outcome the impact (alter, modify, or quit smoking) brought by antismoking advertisement. Table 8 portrayed the Impact of anti-smoking advertisements. Six statements were framed based on 'Impact' criteria on anti-smoking advertisement. It was found that greater agreement (Mean rating > 70 per cent) were secured by the following statement: 'The ad made me feel concerned about the effects of 


\section{ELK ASIA PACIFIC JOURNAL OF MARKETING \& RETAIL MANAGEMENT}

ISSN 2349-2317 (Online); DOI: 10.16962/EAPJMRM/issn. 2349-2317/2018; Volume 9 Issue 4 (2018)

smoking on my health (mean rating 4.46)'. Moreover, standard deviation (SD) was lower in this statement when compared to other statement. 'I made an attempt to quit smoking (Mean rating 3.84)', 'the ad made me feel concerned about the effects of my smoking on health of the person around me (Mean rating 3.66)'. Lower disagreement was obtained by the statement 'I thought about quitting smoking (Mean Rating 3.23)', 'I looked into ways to quit smoking (Approaching Rehab centres, Quit line number) (Mean Rating 3.02)' and 'The ad made me more likely to take steps to reduce my exposure to second-hand smoke (Mean Rating 2.85).

Thus, it was concluded that anti-smoking advertisement have made the smokers to feel concerned about the effects of smoking on his own health as well as on the health of the person around him, and enabled him to make an attempt to quit smoking. Also, the ad made him to think about quitting smoking. But, the Government should provide necessary information related to Rehab Centers and Quit line number in order to support and give hands to smokers to give up (reject) this habitual behaviour.

\section{CONCLUSION:}

According to the results obtained from the study, it was found that anti-smoking advertisement was clear enough to inform the public that 'smoking is not good for health'. Anti-smoking campaign had a 'social message' that talked down to smokers about the 'evil-effects' of smoking and made him feel concerned on his own health as well as on the surroundings. It has made him to stop, think, attempt and quit this harmful behaviour. Thus, it can be concluded that anti-smoking advertisement was found to be very effective in creating awareness among smokers and general public about the detrimental causes of smoking and bring out the desired habitual change. Based on the findings of the study, it was suggested that the anti-smoking campaign should include necessary information related to Rehab centers and Quitline number for consultation, to support, guide and give hands to smokers for speedy recovery from smoking. Also, it is advisable to exercise strict law and action to over control smoking in public places.

\section{REFERENCES:}

Global Youth Tobacco Survey (GYTS) Geneva, World Health Organization, 2009, www.ta6.org/country/india/factsheet 


\section{ELK ASIA PACIFIC JOURNAL OF MARKETING \& RETAIL MANAGEMENT}

ISSN 2349-2317 (Online); DOI: 10.16962/EAPJMRM/issn. 2349-2317/2018; Volume 9 IsSue 4 (2018)

Www.indiancancersocietydelhi.in

https://www.pagepressjournals.org/index.ph

p/hls/article/view/hls.2014.1883/5406

https://www.google.co.in/amp/s/yourstory.c om/2017/07/smoking-india-tobaccodeaths/amp

Booth-Butterfield, M. (2003). Embedded health behaviours from adolescence to adulthood: The Impact of tobacco, Health Communication, 15(2), 171-184.

WHO. Tobacco free initiative. Tobacco facts. Geneva, Switzerland: World Health Organization; 2013. Available from: http://www.who.int/tobacco/mpower/tobacc o_facts/en/

$\underline{\text { https://economictimes.indiatimes.com/indust }}$ ry/cons-products/tobacco/centre-planningto-put-toll-free-quitline-number-on-tobaccopackets/articleshow/61903191.cms

Smith, B. (1998). "Forget messages [...] think about structural change first”, Social Marketing Quarterly, 4, 13-19.

Divya Priya, B. and Revathi Bala, M. (2015). An Opinion Survey on the awareness and presentation of Social Advertisement in Newspapers. International Journal of Sales and Marketing Management Research and Development (IJSMMRD). 5(5), 9.

https://en.wikipedia.org/wiki/Awareness

www.cancerfoundationofindia.org/activities/ tobacc-control/resourcematerial/pdf/sec4prohibition-of-smoking-in-publicplaces.pdf

Jhanjee S. (2011). Tobacco Control in IndiaWhere are we now? Delhi. Psychiatry Journal. 14, 26-32.

Divya Priya, B. and Revathi Bala, M. (2013). A study on the viewers' perception towards the effectiveness of celebrities in Social Advertisements.SJCC Management Research Review, 3(2), 9.

Hansen, J., Winzeler, S., \& Topolinski, S. (2010). When the death makes you smoke: A terror management perspective on the effectiveness of cigarette on-pack warnings.Journal of Experimental Social Psychology, 46(1), 226-228.

Lerner, D (1958). The passing of Traditional Society: modernizing Middle East, Free Press of Glencoe, New York. 
Divya Priya, B. (2017). Impact of Social Advertisement in Rural Coimbatore District

- A Perceptional Analysis (Doctoral Dissertation), Bharathiar University, Coimbatore, India.

\section{LIST OF TABLES}

Table 1 - Smoke-related Awareness

\begin{tabular}{|c|l|c|c|c|c|}
\hline & & \multicolumn{2}{|c|}{ Aware } & \multicolumn{2}{c|}{ Unaware } \\
\cline { 3 - 6 } S.No. & \multicolumn{1}{|c|}{ Smoke-related Awareness } & No. & $\begin{array}{c}\text { Per } \\
\text { cent }\end{array}$ & No. & $\begin{array}{c}\text { Per } \\
\text { cent }\end{array}$ \\
\hline 1. & $\begin{array}{l}\text { Cigarette smoking can cause serious harm to } \\
\text { one's health }\end{array}$ & 144 & 96 & 6 & 4 \\
\hline 2. & $\begin{array}{l}\text { Exposure to smoke from another person's } \\
\text { cigarette causes heart attack }\end{array}$ & 138 & 92 & 12 & 8 \\
\hline
\end{tabular}

Source: Primary Data

Table 2 - Attitude of Smokers' towards regulation of smoking in public places

\begin{tabular}{|c|l|c|c|}
\hline S.No. & $\begin{array}{l}\text { Attitude of smoker's towards regulation of } \\
\text { smoking in public places }\end{array}$ & $\begin{array}{l}\text { No. } \\
\text { Respondents }\end{array}$ & Per cent \\
\hline 1. & I support the regulation of smoking in public places & 86 & 57.3 \\
\hline 2. & $\begin{array}{l}\text { I never support the regulation of smoking in public } \\
\text { places }\end{array}$ & 64 & 42.7 \\
\hline \multicolumn{2}{|r|}{ Total } & 150 & 100 \\
\hline
\end{tabular}

Source: Primary Data 
ELK ASIA PACIFIC JOURNAL OF MARKETING \& RETAIL MANAGEMENT

ISSN 2349-2317 (Online); DOI: 10.16962/EAPJMRM/issn. 2349-2317/2018; Volume 9 Issue 4 (2018)

Table 3 - Effective media to sell 'Anti-smoking' Advertisement

\begin{tabular}{|c|l|c|c|}
\hline S.No. & \multicolumn{1}{|c|}{ Effective media to sell Anti-smoking Advertisement } & $\begin{array}{c}\text { Mean } \\
\text { Score }\end{array}$ & Rank \\
\hline 1. & Television and Radio & 4.29 & 2 \\
\hline 2. & Newspapers, Pamphlets and Magazines & 3.84 & 7 \\
\hline 3. & Schools and Colleges & 3.88 & 5 \\
\hline 4. & Transit Advertising and wraps (In Buses, Rails, Taxis & 4.20 & 3 \\
\hline 5. & $\begin{array}{l}\text { Posters, banners, hoardings and bill boards (Kept in busy } \\
\text { places) }\end{array}$ & 3.9 & 4 \\
\hline 6. & Ad in cinema theatre / In film Advertisement (Anti-smoking & 4.32 & 1 \\
\hline
\end{tabular}

\section{Source: Primary Data - Interview Schedule}

Table 4 - Message format of Anti-smoking Advertisement viewed

\begin{tabular}{|c|l|c|c|}
\hline S.No. & \multicolumn{1}{|c|}{ Format of Anti-smoke Advertisement } & $\begin{array}{c}\text { No. of } \\
\text { Respondents }\end{array}$ & Per cent \\
\hline 1. & Illness/Social Acceptance Ads & 31 & 20.7 \\
\hline 2. & Graphic health warnings & 60 & 40 \\
\hline 3. & Health-related warnings on cigarette pack & 47 & 31.3 \\
\hline 4. & Fear appeal based and Emotional Ads & 12 & 8 \\
\hline
\end{tabular}

Source: Primary Data - Interview Schedule

Table 5 - Frequency of viewing Anti-smoking Advertisement

\begin{tabular}{|l|l|c|c|}
\hline S.No. & \multicolumn{1}{|c|}{ Frequency of viewing Anti-smoke Advertisement } & $\begin{array}{c}\text { No. of } \\
\text { Respondents }\end{array}$ & Per cent \\
\hline 1. & Regularly & 37 & 24.7 \\
\hline 2. & Occasionally & 41 & 27.3 \\
\hline 3. & When necessity arise & 42 & 28 \\
\hline 4. & During leisure time & 18 & 12 \\
\hline 5 & $\Delta \pm$ Same unavoidable situation & 12 & 8 \\
\hline
\end{tabular}

Source: Primary Data - Interview Schedule 
ELK ASIA PACIFIC JOURNAL OF MARKETING \& RETAIL MANAGEMENT

ISSN 2349-2317 (Online); DOI: 10.16962/EAPJMRM/issn. 2349-2317/2018; Volume 9 Issue 4 (2018)

Table 6 - Effectiveness of Anti-smoking Advertisement

\begin{tabular}{|c|c|c|c|c|c|c|}
\hline S.No. & $\begin{array}{c}\text { Effectiveness of Anti-smoking } \\
\text { Advertisement }\end{array}$ & $\mathbf{N}$ & Minimum & Maximum & $\begin{array}{l}\text { Mean } \\
\text { Rating }\end{array}$ & SD \\
\hline 1. & $\begin{array}{l}\text { Anti-smoking advertisement was } \\
\text { clear enough to inform the public } \\
\text { that smoking is not good for health }\end{array}$ & 150 & 1 & 5 & 4.15 & 1.13 \\
\hline 2. & $\begin{array}{l}\text { Anti-smoking advertisement had a } \\
\text { social message that is important to } \\
\text { me }\end{array}$ & 150 & 1 & 5 & 3.52 & 1.21 \\
\hline 3. & $\begin{array}{l}\text { Anti-smoking advertisement said } \\
\text { things that were hard to believe }\end{array}$ & 150 & 1 & 5 & 3.24 & 0.96 \\
\hline 4. & $\begin{array}{l}\text { Anti-smoking advertisement made } \\
\text { me stop and think about quitting } \\
\text { smoking }\end{array}$ & 150 & 1 & 5 & 3.43 & 1.28 \\
\hline 5. & $\begin{array}{l}\text { Anti-smoking advertisement made } \\
\text { me curious to know about things that } \\
\text { are likely to occur }\end{array}$ & 150 & 1 & 5 & 3.19 & 1.78 \\
\hline 6. & $\begin{array}{l}\text { Anti-smoking advertisement } \\
\text { informed about the consequences } \\
\text { and illness due to smoking }\end{array}$ & 150 & 1 & 5 & 3.07 & 1.21 \\
\hline 7. & $\begin{array}{l}\text { Anti-smoking advertisement gave } \\
\text { me information related to Rehab } \\
\text { centers and quit line toll-free number }\end{array}$ & 150 & 1 & 5 & 2.99 & 1.28 \\
\hline 8. & $\begin{array}{l}\text { Anti-smoking advertisement talked } \\
\text { down to me }\end{array}$ & 150 & 1 & 5 & 3.72 & 1.08 \\
\hline 9. & $\begin{array}{l}\text { Anti-smoking advertisement made } \\
\text { me feel worried }\end{array}$ & 150 & 1 & 5 & 3.23 & 1.39 \\
\hline 10. & $\begin{array}{l}\text { Anti-smoking advertisement made } \\
\text { me to give up smoking in public }\end{array}$ & 150 & 1 & 5 & 3.13 & 1.14 \\
\hline
\end{tabular}

Source: Primary Data 
ELK ASIA PACIFIC JOURNAL OF MARKETING \& RETAIL MANAGEMENT

ISSN 2349-2317 (Online); DOI: 10.16962/EAPJMRM/issn. 2349-2317/2018; Volume 9 Issue 4 (2018)

Table 7 - Recollection of Anti-smoking Advertisement

\begin{tabular}{|c|l|c|c|c|c|c|c|}
\hline \multirow{2}{*}{ S.No. } & \multicolumn{2}{|c|}{ Message Type } & \multicolumn{2}{|c|}{ High } & \multicolumn{2}{|c|}{ Low } & \multicolumn{2}{|c|}{ No } \\
\cline { 3 - 8 } & No. & $\begin{array}{l}\text { Per } \\
\text { cent }\end{array}$ & No. & Per cent & No. $\begin{array}{l}\text { Per } \\
\text { cent }\end{array}$ \\
\hline 1. & $\begin{array}{l}\text { Illness/Social Acceptance } \\
\text { Ads }\end{array}$ & 60 & 40 & 59 & 39.3 & 31 & 20.7 \\
\hline 2. & Graphic health warnings & 48 & 32 & 41 & 27.3 & 61 & 40.7 \\
\hline 3. & $\begin{array}{l}\text { Health-related warnings on } \\
\text { cigarette pack }\end{array}$ & 55 & 36.7 & 36 & 24 & 59 & 39.3 \\
\hline 4. & $\begin{array}{l}\text { Fear appeal based and } \\
\text { Emotional Ads }\end{array}$ & 43 & 28.7 & 65 & 43.3 & 42 & 28 \\
\hline
\end{tabular}

Source: Primary Data

Table 8 - Impact of Anti-smoke Advertisement

\begin{tabular}{|c|l|c|c|c|c|c|}
\hline S.No. & \multicolumn{1}{|c|}{ Impact of Anti-smoke Ad } & N & Minimum & Maximum & $\begin{array}{c}\text { Mean } \\
\text { Rating }\end{array}$ & SD \\
\hline 1. & $\begin{array}{l}\text { The ad made me feel concerned } \\
\text { about the effects of smoking on } \\
\text { my health }\end{array}$ & 150 & 1 & 5 & 4.46 & 0.97 \\
\hline 2. & $\begin{array}{l}\text { The ad made me feel concerned } \\
\text { about the effects of my smoking } \\
\text { on health of the person around } \\
\text { me }\end{array}$ & 150 & 1 & 5 & 3.66 & 1.18 \\
\hline 3. & $\begin{array}{l}\text { I thought about quitting smoking } \\
\text { smoking (Approaching Rehab } \\
\text { centres, Quit line number) }\end{array}$ & 150 & 1 & 5 & 3.23 & 1.39 \\
\hline 5. & $\begin{array}{l}\text { I made an attempt to quit } \\
\text { smoking }\end{array}$ & 150 & 1 & 5 & 3.84 & 1.33 \\
\hline 6. & The ad made me more & 150 & 1 & 5 & 2.85 & 1.08 \\
\hline
\end{tabular}


ELK ASIA PACIFIC JOURNAL OF MARKETING \& RETAIL MANAGEMENT

ISSN 2349-2317 (Online); DOI: 10.16962/EAPJMRM/issn. 2349-2317/2018; Volume 9 Issue 4 (2018)

\begin{tabular}{|l|l|l|l|l|l|l|}
\hline $\begin{array}{l}\text { likely to take steps to reduce my } \\
\text { exposure to second-hand smoke }\end{array}$ & & & & & \\
\hline
\end{tabular}

Source: Primary Data 